Karolina Studnicka-Mariańczyk

Zaktad Historii XIX wieku, Instytut Historii

Wydziat Filologiczno-Historyczny

Akademia im. Jana Dlugosza w Częstochowa

\title{
Wykształcenie ziemiańskie i jego wpływ na wychowanie dzieci na przykładzie rodu Ostrowskich Korabitów
}

\begin{abstract}
Manorial education and its influence on the upbringing of children - the example of Aleksander Ostrowski of the Korab family.

The article presents the subsequent stages of Aleksander Ostrowski's education; it shows his successes at school, and also points at the direct link between the economic achievements of the Ostrowskis' domain and the level of the owners' education. The general and professional knowledge acquired at school and the level of culture and civil awareness provided resulted in the formation of high educational ambitions also in the next generation: the atmosphere of the family home and the pedagogical attitude of Aleksander and Helena Ostrowski influenced the fact that their children were also well educated; therefore, they could continue the family traditions, develop their farm, and participate in political life.

The example of the Ostrowski family from Maluszyn can serve as an argument justifying the statement that a high level of education should be treated as a main factor in forming certain types of world views, social and political beliefs, and the level of interest and participation in culture. It should also be treated as a factor determining openness towards innovations and progress in both the organisation of social life and the economy.
\end{abstract}

Keywords: Aleksander Ostrowski, education, upbringing children, gentry

W XIX w. funkcjonował typ ziemianina niezbyt wykształconego, ograniczającego swoje lektury do Biblii, herbarzy i kalendarzy gospodarskich, obracającego się tylko w kręgu spraw majątku, gospodarki i codziennych warunków bytu. Nie zajmując się czytaniem, nauką czy polityką, czas wolny spędzał na spotkaniach sąsiedzkich, proszonych obiadach, organizowanych przez okoliczne dwory spotkaniach, kuligach i innych rozrywkach. Nie brakowało też jednak ziemian światłych, którzy zajmowali się studiowaniem różnych nauk, nierzadko poświęcając swym pasjom znaczną część wolnego czasu. Linią podziału tych dwóch typów zachowań ziemiaństwa było przede wszystkim 


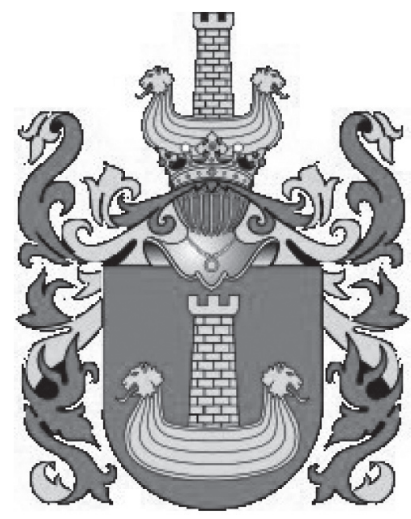

\author{
Rys. 1. Herb szlachecki Korab \\ Źródło: T. Gajl, Herbarz polski. Od średniowiecza do XX w.,
} Gdańsk 2007, s. 164

wykształcenie, które uważać należy za główny czynnik kształtujący światopogląd społeczny, polityczny czy kulturalny poszczególnych członków danego rodu. Miało ono także znaczny wpływ na ich działalność gospodarczą i karierę polityczną. Najlepszym przykładem, potwierdzającym powyższą tezę jest rodzina Ostrowskich Korabitów ${ }^{1}$.

Aleksander Ostrowski herbu Korab urodził się 12 września 1810 r. w Warszawie 2. Matka - Józefa z Potockich - wywierała duży wpływ na naukę syna, o czym świadczy korespondencja rodziny Ostrowskich. W wieku 12 lat został młody dziedzic „oddany na naukę" do szkół publicznych. Od września 1821 r. do końca roku szkolnego 1824 r. uczęszczał do Liceum Warszawskiego ${ }^{3}$, a następnie do kolegium księży pijarów na Żoliborzu, w którym to pozostał aż do roku $1827^{4}$.

Aleksander Ostrowski, jak wynika z materiałów i dokumentów rodzinnych, miał doskonałe wyniki w nauce. Jeszcze w liceum wychowawca - Samuel Bogumił Linde - zaznaczył, że we wszystkich tych klasach publiczne odbierat pochwały. Sprawowat sie wzorowo ${ }^{5}$. Za wzorową edukację oraz zachowanie otrzymywał oceny celujące, a następnie w roku 1825 i 1827 zaszczytny tytuł „Księcia Młodzieży”. Był to najwyższy stopień dla uczniów kolegium. Niższe stopnie od Aleksandra otrzymali jego koledzy ze szkolnej ławy: Antoni Lesznowski, Henryk Potocki (cioteczny brat Aleksandra), Leopold Poletył-

${ }^{1}$ Historia rodziny Ostrowskich Korabitów z Maluszyna jest przedmiotem pracy badawczej Autorki niniejszej publikacji. Ich wyniki przedstawia dysertacja doktorska pt. Domena Ostrowskich z Maluszyna, jako przyktad przemian kapitalistycznych $w$ rolnictwie polskim XIX wieku, Częstochowa 2011 oraz opracowana monografia pt. Siedziba ziemiańska Ostrowskich Korabiów w Maluszynie, Częstochowa 2012 (w druku).

2 Wielka encyklopedia powszechna ilustrowana, tzw. Encyklopedia Sikorskiego, podaje na stronie 840, że Aleksander Ostrowski urodził się w Maluszynie (WEPI, seria II, t. 6, z. 48a); tymczasem Polski słownik biograficzny (PSB, t. 24, Wrocław 1979, s. 538) jako miejsce urodzenia hrabiego wskazuje Warszawę, tak również stwierdza Helena Ostrowska; zob. Dzieje Maluszyna i jego dziedziców..., s. 54.

${ }^{3}$ Archiwum Państwowe w Łodzi (dalej: APŁ), Archiwum Potockich i Ostrowskich z Maluszyna (dalej: APiOM), Papiery Aleksandra Ostrowskiego dotyczące jego nauki, sygn. II/70.

${ }^{4}$ Aleksander Ostrowski, w: PSB, s. 538.

5 APŁ, APiOM, Papiery Aleksandra Ostrowskiego dotyczące jego nauki, sygn. II/70.

${ }^{6}$ Ibidem. 
Fot. 1. Aleksander hrabia Ostrowski herbu Korab (1810-1896). Syn Wojciecha Ostrowskiego i Józefy Potockiej herbu Pilawa (Złota)

Źródło: APŁ, APiOM, Zbiór fotografii i albumów

Ostrowskich, Potockich, Morsztynów i rodzin spokrewnionych, sygn. IV/109, f.157.

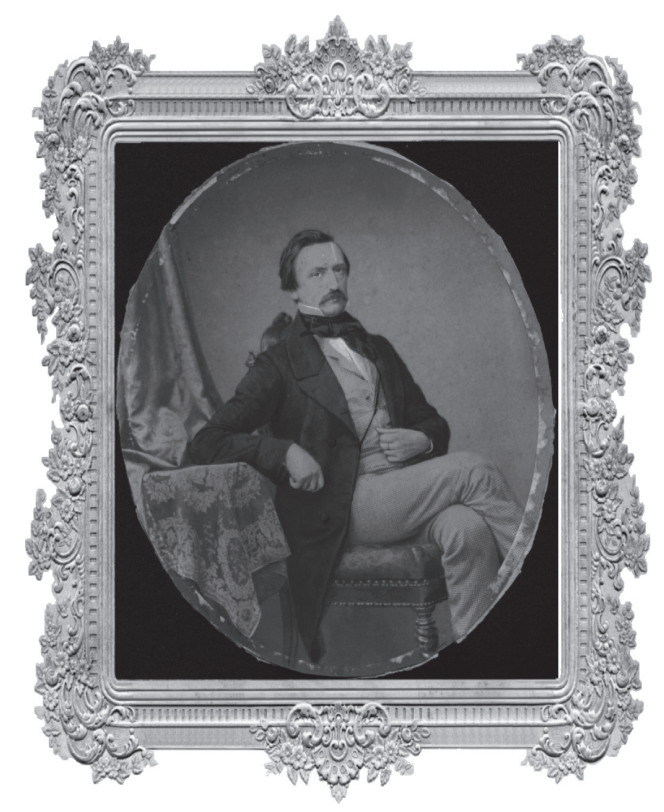

ło i Bernard Halpert. Na tym jednak sukcesy edukacyjne młodego Aleksandra Ostrowskiego się nie kończyły.

W jednym z wydań „Kuriera Warszawskiego” z roku 1827 zamieszczono tekst poświęcony popisowi uczniów konwiktu żoliborskiego. Tak brzmi fragment owego zapisu:

JW. Minister Oświecenia oświadczywszy JJPP Konwiktorom swoje ukontentowanie, ogłosit imiona zastugujacych na pochwatę i nagrody, które mieli szczęście odebrać z rąk JW. Naczelnika Rząu Krajowego. Nagrody większe w ksiązkach, jako przez wszystkie 4ry kwartaty Urzędnicy młodzieży Konwiktu, otrzymali: Ostrowski Alexander, Frankowski Julian, Frankowski Konstanty. Nagrodę druga w ksiązkach jako Urzędnicy przez 3 ostatnie kwartaty otrzymali: Walewski Konrad, Potkański Ludwik, Benoe August, Truszczyński Prosper, Pawłowski Artur. Nagrodę mniejsza w laurach otrzymali: Czosnowski Wincenty, Poletyło Leopold, Potocki Henryk, Lesznowski Antoni, Krasowski Zenon, Mściwojewski Roman, Sottyk Stanisław, Oskierka Jan, Dzwonkowski Adam, Wielopolski Bolesław, Halpert Bernard, Lemański Ludwik, Kosowski Maciej, Potocki Maurycy, Rzewuski Witold, Grabowski Adolf, Garczyński Antoni, Łęski Ludwik, Siemieński Leon, Surowiecki Przemysław, Mikulski Franciszek, Gordon Karol, Szulbowski Stefan, Lubieniecki Hippolit, Mioduski Stanisław, Swidziński Napoleon ${ }^{7}$

\footnotetext{
7 Ibidem.
} 
Tabela 1. Oceny i opinia o Aleksandrze Ostrowskim, uczniu klasy 5

(I półrocze roku szkolnego 1824/1825)

\begin{tabular}{|c|c|c|c|c|c|c|}
\hline $\begin{array}{c}\text { Imię } \\
\text { i } \\
\text { na- } \\
\text { zwi- } \\
\text { sko }\end{array}$ & $\begin{array}{l}\text { Tem- } \\
\text { pera- } \\
\text { ment }\end{array}$ & $\begin{array}{l}\text { Władze } \\
\text { umysłowe } \\
\text { i zdolności }\end{array}$ & $\begin{array}{l}\text { Pilność w lekcjach, } \\
\text { kompozycjach i czytaniu } \\
\text { dobrych książek }\end{array}$ & Obyczaje & $\begin{array}{c}\text { Postępek } \\
\text { w każdej } \\
\text { z osobna nauce }\end{array}$ & $\begin{array}{c}\text { Uwagi } \\
\text { szczególne }\end{array}$ \\
\hline \multirow{9}{*}{ 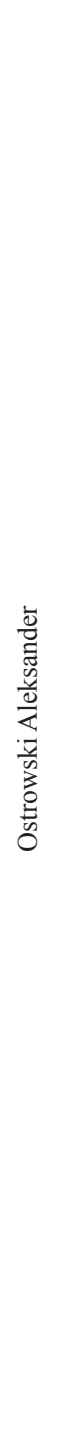 } & $\begin{array}{l}\text { Umiar- } \\
\text { kowa- } \\
\text { ny }\end{array}$ & $\begin{array}{c}\text { pojęcie } \\
\text { takowe } \\
\text { - pamięć } \\
\text { trwała } \\
\text { - uwaga } \\
\text { baczna } \\
\text { - zdolności } \\
\text { znakomite } \\
\end{array}$ & $\begin{array}{c}\text { pilny w gotowaniu się na } \\
\text { lekcje, ma upodobanie } \\
\text { w czytaniu użytecznych } \\
\text { książek }\end{array}$ & chwalebne & $\begin{array}{c}\text { w języku } \\
\text { polskim } \\
\text { i literaturze } \\
\text { bardzo znaczny } \\
\text { Jakubowski }\end{array}$ & - \\
\hline & ditto & ditto & $\begin{array}{l}\text { w gotowaniu się na lekcje } \\
\text { niezmordowany, w } \\
\text { dodawaniu kompozycji } \\
\text { regularny }\end{array}$ & niewinne & $\begin{array}{l}\text { w tłumaczeniu } \\
\text { autorów } \\
\text { łacińskich proza } \\
\text { celujący - } \\
\text { w kompozycjach } \\
\text { mocny Jeżowski }\end{array}$ & $\begin{array}{l}\text { w dobrem } \\
\text { sprawowaniu } \\
\text { się za wzór } \\
\text { dla innych } \\
\text { służyć może }\end{array}$ \\
\hline & ditto & ditto & wzorowa & $\begin{array}{l}\text { przykład- } \\
\text { ne }\end{array}$ & $\begin{array}{c}\text { celujący } \\
\text { w geometrii } \\
\text { i algebrze } \\
\text { Wręczycki }\end{array}$ & - \\
\hline & ditto & ditto & ditto & ditto & $\begin{array}{c}\text { znaczny } \\
\text { przykład religii } \\
\text { i moralny }\end{array}$ & - \\
\hline & ditto & $\begin{array}{c}\text { pojęcie } \\
\text { takowe } \\
\text { - pamięć } \\
\text { trwała } \\
\text {-uwaga zawsze } \\
\text { przedmiotem } \\
\text { lekcji zajęta }\end{array}$ & $\begin{array}{c}\text { godna ze wszystkich miar } \\
\text { pochwały }\end{array}$ & $\begin{array}{l}\text { Jakie } \\
\text { zdobią } \\
\text { młodzień- } \\
\text { ców }\end{array}$ & $\begin{array}{c}\text { wielki w historii } \\
\text { i botanice } \\
\text { Strzałecki }\end{array}$ & - \\
\hline & ditto & ditto & ditto & ditto & $\begin{array}{c}\text { celujący w fizyce } \\
\text { i botanice } \\
\text { Kurowski }\end{array}$ & - \\
\hline & ditto & wyborne & ditto & wzorowe & $\begin{array}{c}\text { celujący } \\
\text { w poezji } \\
\text { łacińskiej i języku } \\
\text { greckim } \\
\end{array}$ & - \\
\hline & ditto & ditto & dobra & ditto & $\begin{array}{l}\text { dobry w języku } \\
\text { francuskim } \\
\text { Coehet }\end{array}$ & - \\
\hline & ditto & dobre & dobra & dobre & $\begin{array}{c}\text { znaczny } \\
\text { w języku } \\
\text { niemieckim }\end{array}$ & - \\
\hline
\end{tabular}

,--" brak danych (dalej: b.d.)

Źródło: APŁ, APiOM, Papiery Aleksandra Ostrowskiego dotyczące jego nauki, sygn. II/70, s. 103. 
Na przytoczenie zasługuje także opinia pijara opiekującego się młodym Aleksandrem Ostrowskim, niejakiego A. W. Jakubowskiego:

Nie mogąc skłonić Pana Alexandra do przesłania JW. Panu zaszczytnych Dyplomatów, które na pierwsza godność pomiędzy wspótuczniami otrzymat, odważytem się korzystać z jego nieprzytomności, załaczyć je do tego listu, w zaufaniu, że lubo ten mój postępek zasmuci nieco obrażona skromność Pana Alexandra, radościa jednak napetni jego Najszanowniejszych Rodziców serce i da Im zupetna pewność o moralnym postępowaniu $i$ wzorowej pilności godnego Ich syna ${ }^{8}$.

Z zachowanych dokumentów Ostrowskich oraz zeszytów szkolnych wynika, że Aleksander nie lubił i nie interesował się poezją, literaturą oraz sztuką (co nie przeszkadzało w uzyskiwaniu celujących ocen szkolnych z przedmiotów humanistycznych). Szczególnie wyśmiewał literaturę lekką, zwłaszcza tak chętnie czytane w owym czasie romanse, których lekturę nazywał: la plus dangereuse des volupte („,co najwyżej niebezpieczną rozkoszą"). Z nieskrywaną pasją interesował się naukami ścisłymi i przyrodniczymi, które to zainteresowania do końca swojego życia rozwijał i szczerze lubił. Astronomia, matematyka i fizyka były jego ulubionymi przedmiotami ${ }^{9}$.

Pomimo że rodzice nie szczędzili na wydatki związane z pobytem Aleksandra w stolicy, był on już od najmłodszych lat bardzo oszczędny. Dowodem na to jest korespondencja, którą prowadził z matką, zdając dokładne relacje ze swoich wydatków. Przykładowo - całoroczny rachunek na potrzeby Aleksandra za rok szkolny 1824/1825 wynosił 3648 złotych i 12 groszy, wliczając w to koszty utrzymania młodego Aleksandra Ostrowskiego oraz pensje i honoraria dla nauczycieli (pijar A. W. Jakubowski otrzymywał $180 \mathrm{zl})^{10}$. Dla porównania: w następnym roku wydatki jego ojca, Wojciecha, związane z pobytami W stolicy, osiągnęły wartość 4068 zł i $24 \mathrm{gr}^{11}$. Sam natomiast Aleksander przez cały rok pobytu w Warszawie w roku 1825/1826 wydał na osobiste potrzeby 1195 złotych i 25 groszy. Wyliczenie to obrazuje tabela 2 :

Tabela 2. Spis wydatków Aleksandra Ostrowskiego za rok 1825/1826

\begin{tabular}{l|c|c|c|}
\hline \multicolumn{2}{|c|}{ Miesiące } & Złotych & Groszy \\
\hline 1825 & Październik & 100 & 22 \\
- & Listopad & 76 & 9 \\
- & Grudzień & 197 & 10 \\
1826 & Styczeń & 119 & 11 \\
- & Luty & 71 & 24 \\
- & Marzec & 107 & 15 \\
${ }^{8}$ Ibidem. \\
9 L. Górski, Aleksander Ostrowski, „Słowo” 1896, nr 192, s. 7. \\
10 APŁ, APiOM, Papiery Aleksandra Ostrowskiego dotyczące jego nauki, sygn. II/70. \\
${ }^{11}$ Ibidem.
\end{tabular}




\begin{tabular}{|c|c|c|c|}
\hline- & Kwiecień & 35 & 6 \\
- & Maj & 146 & 29 \\
- & Czerwiec & 126 & 9 \\
- & Lipiec & 158 & 15 \\
- & \multicolumn{2}{|c|}{-} \\
\hline \multicolumn{2}{|c|}{-} & 1140 & - \\
\hline- & Do tego dodać należy opuszczoną należytość metrowi muzyki & 48 & - \\
\hline- & za miesiąc lipiec & 1188 & 25 \\
\hline- & Rok czyni & 7 & 25 \\
\hline
\end{tabular}

,-" b.d.

Źródto: APŁ, APiOM, Papiery Aleksandra Ostrowskiego dotyczące jego nauki, sygn. II/70, s. 39.

W 1827 r. wstąpił Aleksander Ostrowski na Uniwersytet Warszawski, gdzie rozpoczął studia na wydziale prawa. Po dwóch latach edukacji wraz z Henrykiem Potockim wyjechał na studia do Monachium, gdzie wstąpił na Uniwersytet króla Ludwika Maksymiliana, który to ukończył w 1830 r. Wśród papierów dotyczących nauki młodego dziedzica odnaleźć można zaświadczenia o uczestnictwie w wykładach z np. przedmiotów: prawoznawstwa, historii prawa, rolnictwa, ze znajomości prawa kościelnego, prawa międzynarodowego, technologii chemicznych oraz prawa cywilnego ${ }^{12}$.

W tym samym czasie odbył kilka podróży do Szwajcarii, Rzymu i Włoch ${ }^{13}$. Wspominając czasy swojej młodości, podkreślał wielokrotnie, że zdobyta wiedza i doświadczenie oraz poznani ludzie ukształtowali jego poczucie obowiązku wobec ojczyzny. W czasie swoich podróży spotkał i poznał osobiście Adama Mickiewicza ${ }^{14}$.

W roku 1830 wraz z Henrykiem Potockim wrócił do kraju i wstąpił do wojska. Na początku służby wojskowej był prostym żołnierzem w szwadronie jazdy poznańskiej, gdzie służył pod Kazimierzem Potulickim, a potem - w stopniu oficera - w 5 Pułku Ułanów imienia Zamoyskich, pod komendą Ignacego Kraszewskiego ${ }^{15}$. Z całym korpusem pod wodzą generała Girolamo Ramorino ${ }^{16}$, po przekroczeniu granicy, złożył broń pod Zawichostem. Osadzony - po internowaniu przez Austriaków - w fortecy w Ołomuńcu, Aleksander Ostrowski pozostał tam, wraz ze swoimi towarzyszami, do czasu ogłoszenia amnestii przez cesarza Mikołaja.

12 Ibidem.

13 L. Górski, op. cit., s. 6.

14 Aleksander Ostrowski, w: PSB, s. 539.

15 APŁ, APiOM, Papiery osobiste Aleksandra Ostrowskiego, sygn. II/72.

16 Por.: F. Sznajde, „Wyprawa korpusu Ramorino do Brześcia. Ustęp z Kampanii 1831, Cz. 2-ga, Dowody, uwagi i przypiski”, rękopis w zbiorach Biblioteki Kórnickiej PAN, dostępny: www.wbc.poznan.pl:134295 [data dostępu: 07.08.2010]. 
Fot. 2. Helena Karolina hrabina Morstin herbu Leliwa (1815-1892). Córka Ludwika Felicjana Kajetana hrabiego Morstin i Marii hrabiny Rawity-Ostrowskiej herbu Rawicz. Żona Aleksandra hrabiego Ostrowskiego

Źródło: APŁ, APiOM, Zbiór fotografii i albumów Ostrowskich, Potockich, Morsztynów i rodzin spokrewnionych, sygn. IV/109, f. 219.

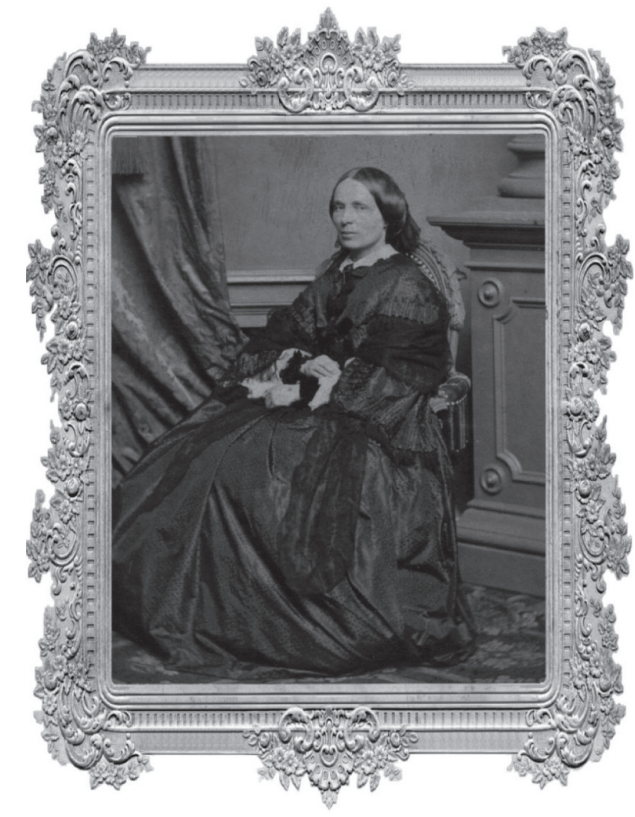

Dwudziestoletni młodzieniec od razu i bez wahania korzystać z niej postanowit. Nie znęciła go zwodnicza myśl emigracyi, której już wtenczas $i$ w ciagu całego życia nie hołdowat. Pragnąt on w kraju pracować dla kraju, jakiekolwiek bylyby tej pracy warunki ${ }^{17}$.

W ten sposób zakończył się jeden z życiowych etapów młodego dziedzica, okres ważny i rzutujący na dalsze losy maluszyńskiego gospodarza. Należy w tym miejscu podkreślić zwłaszcza staranne wykształcenie Aleksandra Ostrowskiego, a więc wartość, która stała się swoistym kapitałem wspomagającym zajęcie znaczącej pozycji w społeczeństwie. Między innymi w tym kontekście można rozpatrywać szeroko zakrojoną działalność polityczną tego ziemianina oraz jego liczne zainteresowania. Wiedza wyniesiona ze szkół, poparta następnie zdobytym doświadczeniem, stanowiła jeden z jego głównych atutów ${ }^{18}$. Świadomość znaczącej rangi dobrego wykształcenia niewątpliwie motywowała aspiracje edukacyjne w kolejnym pokoleniu. Atmosfera domu rodzinnego tworzona przez Aleksandra i jego żonę Helenę z Morsinów Ostrowskich formowała styl wychowania ich dzieci i stymulowała aktywną i akceptującą postawę względem trudów edukacji. Najlepsze owoce owych wysiłków wychowawczo-edukacyjnych przyniosło kształcenie synów Augusta, Jana Leona, Józefa oraz córek Marii i Ludwiki.

Ówczesny model wczesnej edukacji powielał tradycyjne wzorce. Do matki należało zorganizowanie opieki nad dziećmi i zapewnienie im podstaw dla dalszego kształcenia.

${ }^{17}$ L. Górski, op. cit., s. 7.

18 K. Studnicka, Społeczno-gospodarcza działalność Aleksandra Ostrowskiego w latach 1832-1890, w: Silva Rerum Antiquarum. Księga Pamiątkowa dedykowana prof. zw. dr hab. Bartlomiejowi Szyndlerowi, red. R. Szwed, Częstochowa 2009, s. 297-309. 
Do 12-14 roku życia nauka odbywała się w domu, po tym okresie chłopcy podejmowali edukację w gimnazjum, rozszerzając ją ewentualnie o poziom akademicki, dziewczęta zaś pozostawały u boku matki aż do chwili zamążpójścia. Na etapie edukacji domowej starania rodziców wspierali wynajęci w tym celu guwernerzy (guwernantki) i metrowie. Zatrudnienie właściwych nauczycieli, gwarantujących odpowiedni poziom kształcenia, nie było łatwym zadaniem i wymagało wiele czasu i zabiegów. Opierano się przy tym na opiniach krążących w szerszym kręgu rodzinnym i wśród znajomych, kandydaci zaś musieli mieć nie tylko właściwe kwalifikacje, ale i poświadczone referencje. Helenie Ostrowskiej udało się zorganizować małą szkółkę rodzinną, do której uczęszczali chłopcy z kręgu najbliższej rodziny ${ }^{19}$. W gronie zatrudnianych metrów często występowali obcokrajowcy - w Maluszynie starania Polaków uzupełniał Francuz i Szwajcar ${ }^{20}$. Ich obecność niewątpliwie podnosiła poziom nauki języków obcych i zapewne wpływała na późniejszą swobodę $\mathrm{w}$ poruszaniu się wśród arystokratycznego środowiska, a więc w kręgu kulturowym nawiązującym do poziomu kultury europejskiej i obyczajowo-towarzyskich konwenansów. Właścicielka Maluszyna wspomina:

Skreśliwszy, z okoliczności podróży za granicy, której byt uczestnikiem, krótki rys życia Józefa Ostrowskiego, cofam się do jego starszego brata Jana, urodzonego dnia 27-tego listopada 1840 roku. Z dzieciństwa okazywat usposobienie tagodne, zbyt nawet powolne, a przy tym statość woli i powage umystu, które go dotad znamionują. Dopiero skończywszy lat 9, po poprzednich nieszczęśliwych próbach, wraz z dodanym do wspólnego wychowania Bolestawem Skórzewskim, synem Leona i Maryi z hr. Morstinów Skórzewskich, a bratem moim ciotecznym, dostat dobrego nauczyciela Szwajcara, pana Jean Baptiste Groidevaux, który również w niektórych przedmiotach, jako to $w$ języku francuskim i arytmetyce, przychodzit $w$ pomoc $w$ wyksztatceniu Marii Ostrowskiej i Natalii Gadomskiej ${ }^{21}$.

W dalszych słowach Helena Ostrowska pisze:

Cechami pana Jana Ostrowskiego byty wytrwatość w usitowaniach zajęcia się żywym przedmiotem naukowym, zwlaszcza w historii, które to przedmioty zapewniaty mu zawsze znakomite miejsce $w$ klasach i nagrody, skoro idac torem starszego brata, zaczą w roku 1858, pod skrzydłami profesora Puchewicza, uczęszczać wraz z Bolesławem Skórzewskim, do Gimnazjum [20] Realnego, poczynajac od III klasy. Pan Groidevaux przenióst się wtedy z dawnymi uczniami do Warszawy, przyjmując na pensje profesora Puchewicza obowiązi guwernera i nauczyciela francuskiego języka i historii, przedmiotów w Gimnazjum Realnym wcale niewykładanych. Oprócz tego, okazując Jan O[strowski] zamiłowanie do muzyki, która od kilku lat na fortepianie, o ile się da uprawia, $i$ do rysunków, do których obiecanego ma wkrótce osobnego nauczyciela ${ }^{22}$.

Odpowiednio zorganizowany etap edukacji domowej pozwalał bezproblemowo pominąć edukację elementarną i rozpocząć naukę w gimnazjum, a więc na poziomie szkoły średniej. Zwracano przy tym uwagę, na jakość dalszej edukacji. Ostrowscy w tym

19 A.J. Zakrzewski, Z dziejów dziewiętnastowiecznej rodziny ziemiańskiej. Ostrowscy h. Korab z Maluszyna, w: H. Ostrowska, Dzieje Maluszyna i jego dziedziców..., s. 19.

20 Ibidem, s. 70.

${ }^{21}$ Ibidem.

${ }^{22}$ Ibidem, s. 70-71. 
Fot. 3. Jan Leon Ostrowski herbu Korab (1840-1918). Syn Aleksandra Ostrowskiego

i Heleny hrabiny Morstin herbu Leliwa

Źródto: APŁ, APiOM, Zbiór fotografii i albumów Ostrowskich, Potockich, Morsztynów i rodzin spokrewnionych, sygn. IV/111, f. 43.

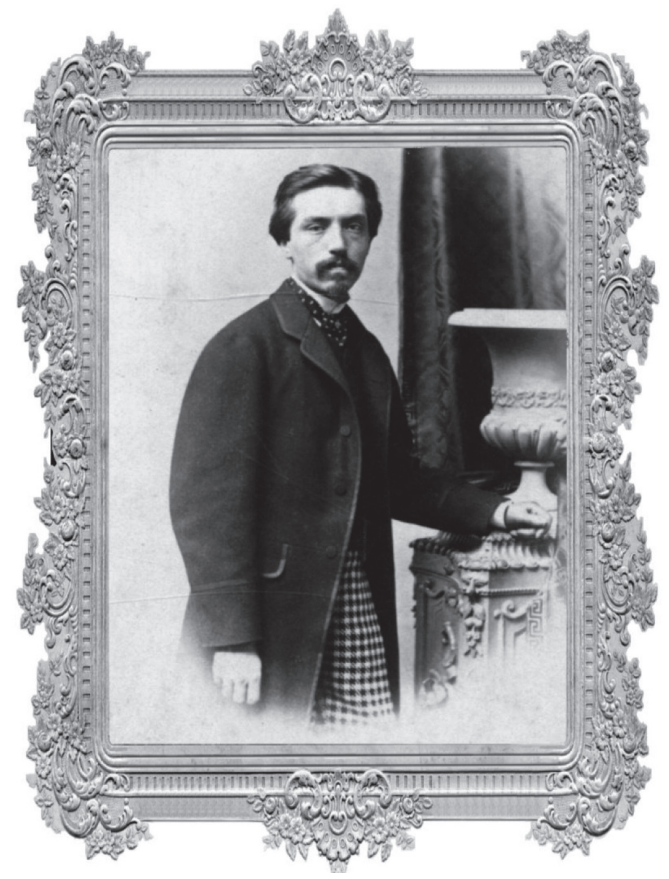

względzie nie mieli wątpliwości, że szkoły warszawskie - stołeczne - są tymi, które gwarantują właściwe środowisko i poziom nauki dla ich dzieci.

Szczególnie dokładnie Helena Ostrowska opisuje w swoim pamiętniku etapy nauki swojego najstarszego syna, Augusta Ostrowskiego. Oto on:

August, syn najstarszy urodzony w Krakowie dnia 26- sierpnia 1863 r., silnie zbudowany i czerstwy, przetrzymawszy w pierwszych latach kilka napadów krupu, chowat się zreszta [II] zdrowo. Do piątego roku życia zostawat pod wytacznym dozorem Matki i jej panny stużacej, Marianny Wybińskiej, która następnie catemu rodzeństwu, z wszelka pilnościa i poświeceniem, zastępowała miejsce bony, aż w roku 1855 poszła za Wincentego Kopczyńskiego, ekonoma w dobrach A[leksandra] Ostrowskiego. Wtedy, to jest w lecie 1841 r., przyjęto do chtopczyny, ażeby go z rąk kobiet wyciagnać i zarazem języka obcego nauczyć, starego wojaka Francuza z czasów napoleońskich, Piotra Dobry, który na przemian, jako pierwszy mentor lub jako stużacy przy dzieciach podtug potrzeby, nie opuszczat ich aż do śmierci swojej $w$ 87-tym roku życia, która nastapiła w kwietniu 1855 r. w Warszawie. Dodanym wtenczas byt za towarzysza Augustowi O[ostrowskiemu] pod nadzór tegoż Dobrego, rówieśnik jego i krewny Stanisław Potocki, syn Tomasza hr. Potockiego, z którym też w roku 1844 przeszedt ze szkoły macierzyńskiej w domu, do Chrzastowa, gdzie pod dozorem biegłego nauczyciela Francuza, pana Jules Berger (?), zawiązała się, że tak powiem, spótka naukowa, a raczej ucząca się, 7-miu uczniów, członków jednej familii, [12] jako to:

3 synowie Tomasza hr. Potockiego, Michat, Antoni i Stanistaw; 2 synowie Henryka D[Dominika], Rodryg i Witold; I syn śp. Tadeusza hr. Ostrowskiego, Stanisław; I syn A[leksandra] Ostrowskiego - August.

Po dwóch latach odbywanych wspólnie nauk, z pomoca oddanego nauczyciela Polaka i miejscowego duchownego, dwaj synowie starsi Tom[asza] Potoc[kiego] oddani zostali do Warsza- 
wy na nauki, reszta zaś uczni pana Berger przeniosła się do Wrocławia do synów Henry[ka] P[otockiego], majach uczęszczać tamże do szkół publicznych.

Bawit się więc August Ostr[owski] póttora roku w Wroctawiu, z wielka korzyścia co do nauki języka niemieckiego, dla doczekania się wieku wejścia do III-ciej klasy szkoty realnej w Warszawie, co nastapiło w roku 1848. Umieszczony z kilku towarzyszami u znakomitego tejże szkoty profesora matematyki, pana Alfonsa Puchewicza, przebiegt chlubnie wszystkie klasy $i$ w roku 1854 złoży egzamin maturitatis, mając lat 18.

Gdy okoliczności ówczesne (wojna w Krymie) przytrudnity, zwłaszcza dla młodzieży, wyjazd za granice, lubo danych za niego [13] zastępce zwolnionym byt August O[trowski] od stużby wojskowej, rok jeden pobierat jeszcze nauke w Warszawie od prywatnych profesorów, zwłaszcza pod opieke profesora Puchewicza, oddając się szczególniej przedmiotom niewyktadanym $w$ szkole realnej i doskonaląc się w języku niemieckim, który miat mu być $w$ dalszym zawodzie naukowym nader potrzebnym.

Jakoż $w$ jesieni wyjeżdżat do akademii agronomicznej w Hohenheimie, towarzyszac matce, udajacej się także na kuracje córki starszej do wód Carnstadt, również w bliskości Stuttgartu położonych. Pierwszy rok akademickiego życia przecedzit wiec prawie jak po okiem matki, odwiedzając ja co kilka dni, zdając sprawę z wszystkich niemal kroków swoich, a uległościa i synowskim uszanowaniem, które go zawsze cechowaty. Z wszelka tez pewnościa, co do jego pilności i moralnego poste ponawia (w niczym nienadwyrężonego śmieszna sprawa studencka, która go wraz z I0-ma kolegami uczyniła przez tydzień więzieniem stanu w twierdzy wurtenburgskiej Asperg) odjechać go mogła matka na drugim roku studiów. [14] W przeciagu tych $d$ wóch lat pobieranych $w$ Hohenheimie, oprócz miejsc zwiedzonych $w$ podróży z matka, jako to: Wiednia, Gratzu (przez Semmering) jako miejsce pobytu w emigracji od 1831 r. witajacego marszałka ówczesnego Sejmu, a bliskiego krewnego Władysława hr. Ostrowskiego; oprócz brzegów Dunaju, od Wiednia do Linz, jeziora: Gmunden, Tischen, Salzburg i Monachium, obją August O[strowski] w miesiacach wakacji, to jest $w$ marcu i wrześniu każdego roku, Belgię, część Szwajcarii i Tyrolu, Lombardię, Neapol i Rzym. Powracając zaś do kraju po ukończonych kursach i zdanym egzaminie, zwiedzit brzegi Renu od Moguncji do kolonii i Drezna. Przybywszy 28 września 1857 r. do rodziców, spędzit 4 miesiace $w$ gronie rodziny i objeżdżając familię i przyjaciót, a 15 stycznia 1858 r. wyruszyt z Maluszyna na Kraków, Berlin do Paryża, gdzie ma uczęszczać na Kursa prawne $i$ wydoskonalić się w naukach ścistych dotąd uprawianych ${ }^{23}$.

August Ostrowski, podobnie jak ojciec w latach młodości, był wzorowym uczniem gimnazjum realnego. Świadczą o tym zachowane wyciągi z raportów nauczycieli ${ }^{24}$. Wśród papierów po Auguście odnaleźć można także „List pochwalny”:

August Ostrowski uczeń klasy III Gimnazjum Realnego w Warszawie przez przeciąg roku szkolnego 1849 wzorowym posłuszeństwem, przykładnym i moralnym sprawowaniem się, usilnością i pracowitością zasłużył na publiczną pochwałę, która się jemu, na zasadzie zatwierdzonej Najwyższej ustawy szkolnej, niniejszym pismem udziela ${ }^{25}$.

A także szereg wyciągów z raportów nauczycielii ${ }^{26}$. Oto jeden z nich:

\footnotetext{
${ }^{23}$ Ibidem, s. 63-66.

${ }^{24}$ APE, APiOM, Papiery osobiste Augusta Ostrowskiego, syna Aleksandra Ostrowskiego, sygn. II/86.

25 Ibidem.

${ }^{26}$ Ibidem.
} 
Tabela. 3. Raport nauczycieli gimnazjum realnego w Warszawie

Wyciąg z raportów nauczycieli gimnazjum realnego w Warszawie z r. s. 1849

Ostrowski August uczeń klasy IV Od. A

\begin{tabular}{|c|c|c|c|c|c|c|c|c|}
\hline \multicolumn{3}{|c|}{ W CIĄGU KWARTAŁU } & Pierwszy & $\begin{array}{l}\text { Uwa- } \\
\text { gi }\end{array}$ & Drugi & $\begin{array}{l}\text { Uwa- } \\
\text { gi }\end{array}$ & Trzeci & Uwagi \\
\hline \multirow[b]{2}{*}{ Opuścił } & \multirow[b]{2}{*}{} & Mszy SS & 1 & & 1 & & , & \multirow{18}{*}{ 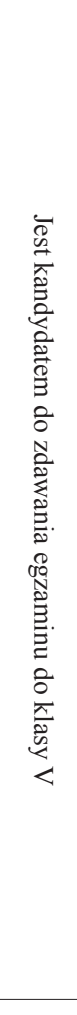 } \\
\hline & & $\begin{array}{l}\text { Lekcji w } \\
\text { klasie }\end{array}$ & 63 & & 24 & & 16 & \\
\hline \multirow{2}{*}{$\begin{array}{l}\text { Sprawował } \\
\text { się }\end{array}$} & \multirow[b]{2}{*}{} & w szkole & \multirow[b]{2}{*}{ wzorowo } & & \multirow[b]{2}{*}{ wzorowo } & & \multirow{2}{*}{$\begin{array}{l}\text { wzo- } \\
\text { rowo }\end{array}$} & \\
\hline & & poza Szkołą & & & & & & \\
\hline \multirow{2}{*}{$\mathrm{W}$ miarę } & \multirow{2}{*}{} & zdolność & dobrej & & dobrej & & & \\
\hline & & pilność & b. dobrej & & b. dobrej & & & \\
\hline \multicolumn{3}{|c|}{ W Nauce Religii i Moralności } & celujący & & celujący & & $\begin{array}{l}\text { celu- } \\
\text { jący }\end{array}$ & \\
\hline \multicolumn{3}{|c|}{ „, Języku Polskim } & dostateczny & & dostateczny & & $\begin{array}{l}\text { dosta- } \\
\text { teczny }\end{array}$ & \\
\hline \multicolumn{3}{|c|}{ „, Języku Rosyjskim } & mierny & & & & & \\
\hline \multicolumn{3}{|c|}{, Języku Niemieckim } & celujący & & celujący & & $\begin{array}{l}\text { celu- } \\
\text { jący }\end{array}$ & \\
\hline \multicolumn{3}{|c|}{,Arytmetyce } & dobry & & dostateczny & & dobry & \\
\hline \multicolumn{3}{|c|}{ „Solidometrii } & celujący & & celujący & & $\begin{array}{l}\text { celu- } \\
\text { jący }\end{array}$ & \\
\hline \multicolumn{3}{|c|}{, Geometrii } & , & & , & & , & \\
\hline \multicolumn{3}{|c|}{, Algebrze } & dostateczny & & dostateczny & & $\begin{array}{l}\text { dosta- } \\
\text { teczny }\end{array}$ & \\
\hline \multicolumn{3}{|c|}{ „, Historii Naturalnej } & dobry & & & & $\begin{array}{l}\text { celu- } \\
\text { jący }\end{array}$ & \\
\hline \multicolumn{3}{|c|}{ „, Geografii } & celujący & & dobry & & dobry & \\
\hline \multicolumn{3}{|c|}{ „, Rysunkach } & dobry & & dostateczny & & Dobry & \\
\hline \multicolumn{3}{|c|}{ „, Kalligrafii } & mierny & & dobry & & $\begin{array}{c}\text { Do- } \\
\text { sta- } \\
\text { teczny }\end{array}$ & \\
\hline \multicolumn{3}{|c|}{ W Warszawie } & 10/22 Grudn & 1850 & \multicolumn{2}{|c|}{ 10/22 Marca 1850} & & \\
\hline
\end{tabular}

Inspektor G.R.

(podpis)

Opiekujący się uczniem

A. Ostrowski

Doskonałe wykształcenie i odbyte podróże zagraniczne ukształtowały syna Aleksandra Ostrowskiego. August starał się tak jak ojciec, uczestniczyć w życiu kraju. Chętnie wspierał ojca, na co dowodem jest jego przynależność do Towarzystwa Kredytowo Ziemskiego i Towarzystwa Rolniczego ${ }^{27}$.

${ }^{27}$ APŁ, APiOM, Akta Augusta Ostrowskiego dotyczące jego działalności publicznej 1861-1882, sygn. II/26. 


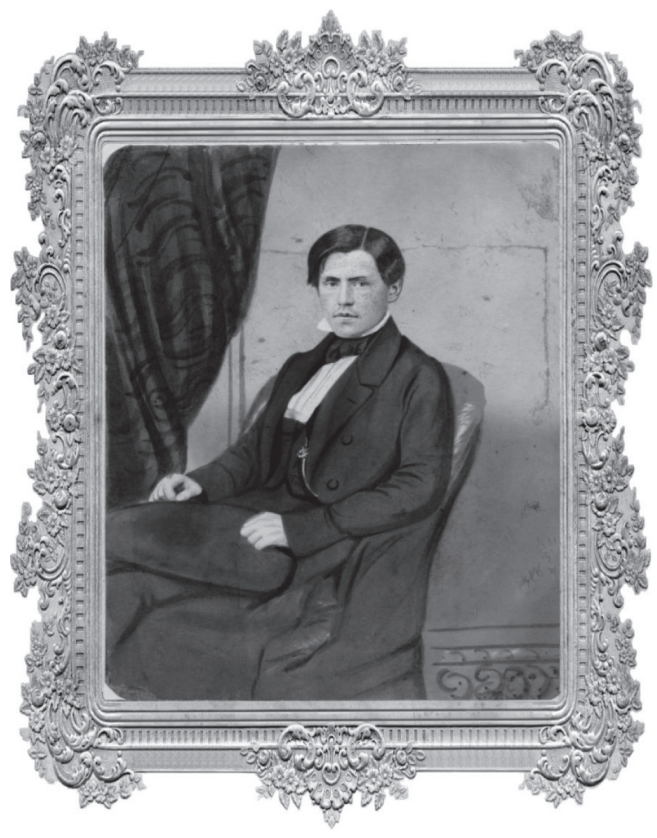

Fot. 4. August Ostrowski herbu Korab (1836-1898). Syn Aleksandra Ostrowskiego i Heleny hrabiny Morstin herbu Leliwa

Źródlo: APŁ, APiOM, Zbiór fotografii i albumów Ostrowskich, Potockich, Morsztynów i rodzin spokrewnionych, sygn. IV/109, f. 219.

Towarzystwo Rolnicze w Królestwie Polskim

Na ogólnym zebraniu w dniu 21 lutego 1861 roku odbytem przyjęto do grona członków czynnych Augusta Ostrowskiego.

W Warszawie dnia 5 kwietnia 1861 roku

Prezes

Andrzej Zamoyski

Członek sekretarz

(podpis)

Młodszy brat Augusta, Józef Ostrowski także otrzymał staranne wykształcenie: po ukończeniu gimnazjum w Warszawie podjął studia w Szkole Głównej Warszawskiej, a następnie w Carskim Uniwersytecie Warszawskim ${ }^{28}$. Na tej właśnie uczelni obronił Aleksander Ostrowski tytuł magistra, prezentując pracę dyplomową z zakresu prawoznawstwa (obecnie znajduje się w zbiorach Biblioteki Narodowej) ${ }^{29}$. Studia prawnicze kontynuował następnie w Berlinie. Był także studentem wydziałów rolniczych w uniwersytetach w Halle i Hohenheimie. Po powrocie do kraju, podobnie zresztą jak ojciec, zajął się działalnością społeczną, gospodarczą i polityczną. Zajmował następujące funkcje: był

\footnotetext{
28 APŁ, APiOM, Papiery osobiste Józefa Ostrowskiego, syna Aleksandra, sygn. II/82.

29 Ibidem, Rozprawa Józefa Ostrowskiego, syna Aleksandra, sygn. II/83.
} 
prezesem Towarzystwa Kredytowo-Ziemskiego w Kaliszu (jak Aleksander Ostrowski), członkiem Rady Redakcyjnej dziennika „Słowo”, jednym z organizatorów Stronnictwa Polityki Realnej (potem prezesem), członkiem rosyjskiej Rady Państwa i prezesem Koła Polskiego, wiceprezesem Związku Kół Królestwa Polskiego i krajów Litwy i Rusi oraz posłem do II Dumy Państwowej i członkiem Rady Regencyjnej (utworzonej w 1917 ro$\mathrm{ku})^{30}$. Warto podkreślić także jego działalność społeczną: był sędzią gminnym, brał udział w pracach przygotowawczych do powołania towarzystw rolniczych, samorządu ziemiańskiego i wiejskiego. Droga jego kariery była podobna do tej, jaką przeszedł Aleksander.

Jeśli chodzi natomiast o Marię i Ludwikę, to niewiele jest zachowanych materiałów źródłowych, dotyczących szkolnej edukacji, co potwierdza przypuszczenia, że nie uczęszczały do szkół publicznych czy też placówek zajmujących się kształceniem dziewcząt.

Zwyczajowo, nauczyciele zajmowali się edukacją chłopców, nauczycielki natomiast odpowiedzialne były za wychowanie i edukację dziewcząt. W przekazie rodzinnym zachowały się nazwiska nauczycielki Katarzyny Konopkówny oraz towarzyszki nauki Marii, Natalii Gadomskiej ${ }^{31}$, co potwierdzają słowa:

O Maryi O[strowskiej] urodzonej dnia 5 lipca w Radoszewnicy, jako odbierajacej liche domowe wychowanie najwłaściwsze kobietom, mało, co jest do wzmiankowania. Sama się nimi matka zajmowała aż do lat 11, wtedy przybrata sobie do pomocy godna [15] nauczycielkę Polkę, pannę Katarzynę Konopkównę, a córce towarzyszkę nauki i zabawy, krewną Natalię Gadom$s k q^{32}$.

Podobnie jak siostra, druga z panien Ostrowskich, Ludwika odebrała jednak najlepsze wykształcenie domowe, jakie było wówczas dostępne dla dziewcząt w Królestwie Polskim $^{33}$. Wskazują na to zachowane teksty napisane przez nią, świadczące o jej szerokich horyzontach myślowych. Znajomość 5 języków obcych, domowe lekcje muzyki, tańca i śpiewu, rysunku oraz haftu potwierdzają powyższe stwierdzenie.

W tym kontekście - sięgając do zasobów rodzinnego archiwum Ostrowskich - warto zwrócić uwagę na niewielką wprawdzie, lecz interesującą notatkę dotyczącą sposobu kształcenia młodych panien w rodzinie Korabitów. Notatka pochodzi jeszcze z początków XIX wieku, a więc dotyczy pokolenia znacznie starszego niż Ludwika, jest jednak cennym świadectwem ciągłości przekazu kulturowego, stylu wychowania i kulturalnego poziomu rodziny. Oto ów dokument ${ }^{34}$ :

30 Ibidem, Akta Józefa Ostrowskiego, tyczące się wyborów do Dumy i Rady Państwa, sygn. II/29.

31 A.J. Zakrzewski, op. cit., s. 18.

32 Ibidem.

33 J. Kita, Ostatnia z rodu-Ludwika z Korabitów Ostrowska, [w:] Ziemiaństwo na Lubelszczyźnie. Panie z dworów i pałaców, t. 3, pod red. H. Łaszkiewicza, Lublin 2007, s. 173.

34 APŁ, APiOM, Akta Ostrowskich, tyczące się spraw majątkowych, sygn. 1/194. 


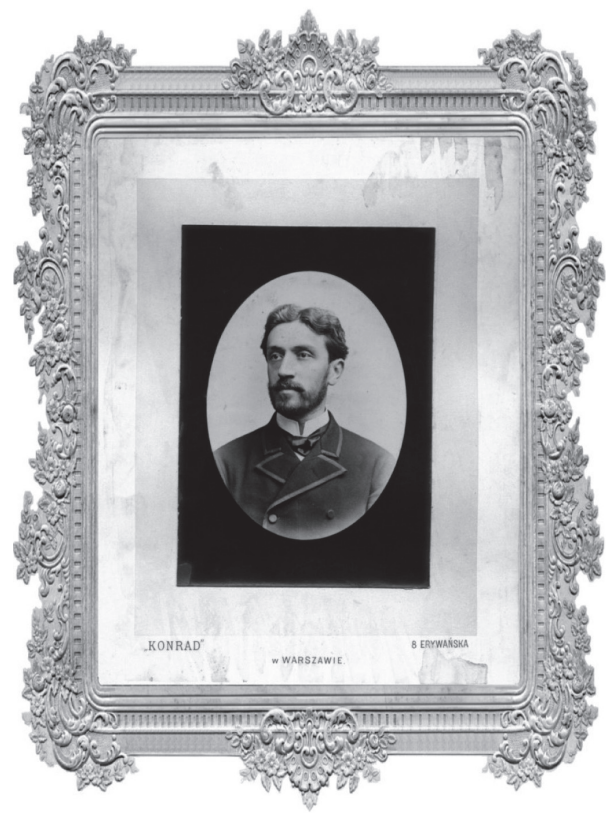

Fot. 5. Józef August Ostrowski herbu Korab (1850-1923). Syn Aleksandra Ostrowskiego i Heleny hrabiny Mostin herbu Leliwa

Źródło: APE, APiOM, Zbiór fotografii i albumów Ostrowskich, Potockich, Morsztynów i rodzin spokrewnionych, sygn. IV/109, f. 131

Niżej wyrażona daję dokument, jako odebrałam z rąk JW. Pana Glińskiego [...] dla Panien Ostrowskich

$\begin{array}{cccc}\# & 6 & \text { na lekcje } & \text { klawikortu } \\ \# & 6 & \text { na lekcje } & \text { gitary } \\ \# & 4 & \text { na lekcje } & \text { tańca } \\ \# & 3 & \text { na lekcje } & \text { śpiewania } \\ \# & 2 & \text { na lekcje } & \text { rysunku } \\ \# & 1 & \text { na lekcje } & \text { haftu }\end{array}$

6 Stycznia Warszawa R. 1809

Wrzesińska

Patrząc na tę notatkę, nie należy zapominać, że jest to jedynie fragment edukacyjnego programu, element, który dziś nazwalibyśmy jako „wychowanie artystyczne”, a więc przedmiot jedynie uzupełniający kształcenie ogólne czy też elementarne. $\mathrm{Z}$ tej perspektywy - może zadziwiać różnorodność zajęć, w tym równoczesna nauka na dwóch, technicznie odmiennych, instrumentach. Dawnymi czasy nie było to jednak czymś nadzwyczajnym. Rozległe wykształcenie muzyczne tworzyło bowiem podstawę kulturalnego życia - wszak nie znano jeszcze radia czy patefonu, a zatem odbiór muzyki wiązał się równocześnie z jej wykonywaniem, kreacją „na żywo” ulubionych utworów i pieśni.

W kolejnych latach życia, dysponując znacznymi środkami finansowymi, Ludwika realizowała proces dalszego samokształcenia, ale przede wszystkim rozwijała swoje zainteresowania. 
Fot. 6. Maria Ostrowska (1838-1925). Córka Aleksandra Ostrowskiego i Heleny hrabiny Morstin herbu Leliwa. Żona Stanisława Jana Władysława Potockiego herbu Pilawa (Złota)

Źródto: APŁ, APiOM, Zbiór fotografii i albumów Ostrowskich, Potockich, Morsztynów i rodzin spokrewnionych, sygn. IV/111, f. 108/11.

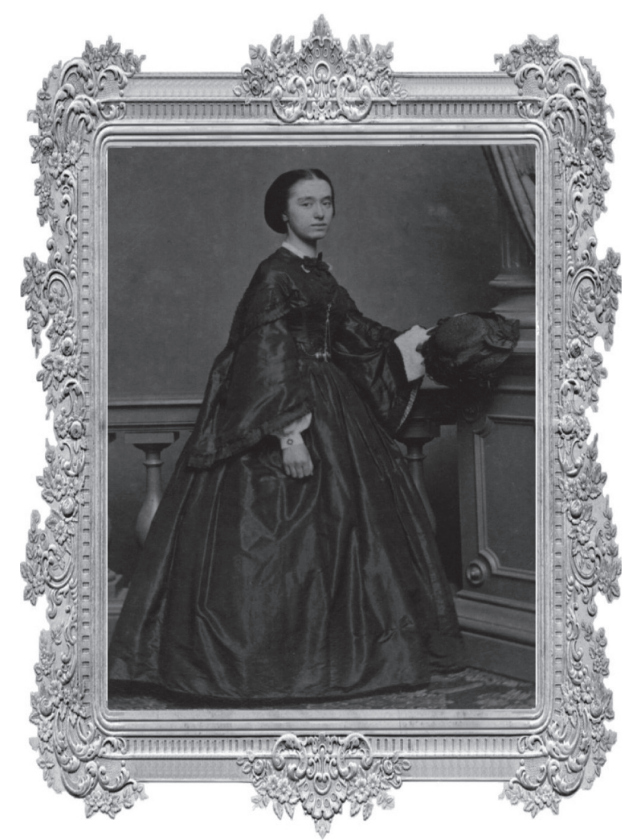

Pasje społecznikowskie Ludwiki Ostrowskiej dobrze oddaje poniższy fragment tekstu przygotowywanego prawdopodobnie do publikacji w którymś z czasopism; jest to również dowód na jej ambicje publicystyczne:

Zajmujac się ubogimi chorymi, przekonatam sie, jak dzieci sq u nas zaniedbywane $i$ widze potrzebę założenia Puponiery z internatem dla dzieci od 6 tygodni do 2, 3 lat-na wzór tych, co sa za granica, lecz zastosowane do naszych potrzeb. Dajmy na to: ojciec stużacym lub woźnym, matka kucharka - dziecko oddaja na garnuszek, gdzie się często marnuje, lub co gorsza, idac do pracy, rodzice bez dozoru dzieci w domu zamykają; wówczas padaja one ofiara pieca, zapatek, topiq się $w$ kubłach z wrzaca woda lub oknem wypadaja na bruk.

We Francji zamiast na garnuszek, niezamożni rodzice umieszczaja dzieci w Puponierze, płacac na ich utrzymanie tyle, co moga, a jak bezdenna bieda, to dziecko chowane jest z ofiarności publicznej.

$W$ takich internatach przez przeciag dwóch lat ksztakca się dozorczynie (bony) zaciagane z grona uczennic szkoły powszechnej, po ukończeniu takowej. Pierwsze 3 miesiace płaca za utrzymanie, dalsze wykształcenie otrzymuja bezpłatnie, jeżeli wykaża zupetne ubóstwo. Po 3 miesiacach, jeśli uczennica okaże się niezdolna i nieodpowiednia, usuwa się ją, bo trzeba bardzo odpowiedni personel kształcić $i$ wyrabiać, nie marnując grosza polskiego.

$W$ internacie musza być infermerje, by w nich umieszczać dzieci lekko niedomagające, jeżeli zaś okaże się coś poważnego lub infekcyjnego, za zgoda rodziców lub opiekunów odsyła się małego pacjenta do szpitala dziecinnego. W razie gdyby Puponiera posiadała filię w leśnej, suchej okolicy lub nad morzem to rekonwalescentów posyła się tam pod opieka dozorczyni.

$W$ bieżacej chwili trzeba ratować dzieci, znajdujace się w barakach, a gdy środki na to nie pozwola trzeba zająć się dziećmi robotników i stużacych. [...]

Ratując dzieci, mamy na widoku palaca kwestię ksztatcenia dozorczyń [...] pod okiem wykwalifikowanych instruktorek. Uniknęlibyśmy wtedy kosztownego sprowadzenia licznych zastępów zagranicznych dozorczyń a jednocześnie otwarłoby się nowe źródło zarobku dla naszych kobiet. 


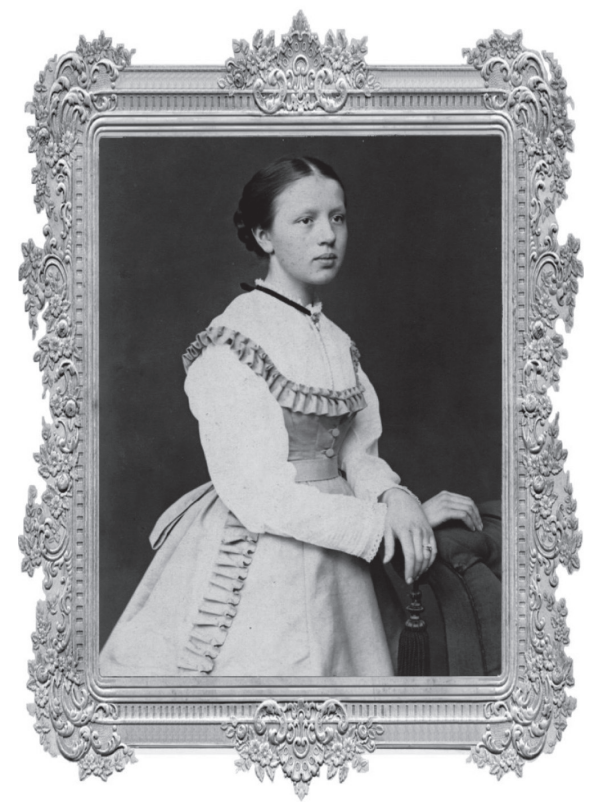

Fot. 7. Ludwika Aleksandra Józefa Ostrowska herbu Korab (1851-1925). Córka Aleksandra Ostrowskiego i Heleny hrabiny Morsin herbu Leliwa

Źródto: APŁ, APiOM, Zbiór fotografii i albumów Ostrowskich, Potockich, Morsztynów i rodzin spokrewnionych, sygn. IV/109, f. 181.

W Paryżu w niektórych wielkich magazynach (u nas takich nie ma) przychodzac rano do pracy, matki dzieci z soba zabieraja i pod opieka fachowo wyksztatconych dozorczyń zostawiaja takowe w miejscowej Puponierze. W wolnych chwilach schodza do niej i karmia swoje niemowleta; wieczór zabieraja je do domów. Jeżeli okazuje się tego potrzeba, dzieci mlekiem dokarmiaja, starsze zaś pożywienie odpowiednie ich wiekowi.

To już szczyt kultury! Może za lat sto do tego u nas dojdziemy. Tymczasem czynimy to, co w naszym zakresie jest możliwe. Niech myśl rzucona padnie na dobra glebę, rychło zakietkuje $i$ wyda porzadny plon ${ }^{35}$.

Pomysł Ludwiki Ostrowskiej, wzorowany na rozwiązaniach francuskich, należy uznać za dość interesujący, choć równocześnie jednak chyba mało praktyczny. Odbija się w nim wyraźnie społecznikowska postawa autorki i charakterystyczny sposób myślenia, nacechowany w jakiejś mierze idealizmem właściwym dla ówczesnych pozytywistów. Można czynić zastrzeżenia, czy idea tworzenia „puponier”, a więc placówek opiekuńczych łączących funkcje żłobka, przedszkola i internatu jest rozwiązaniem właściwym, zważywszy na konieczną różnorodność form opieki w tego rodzaju instytucji. Inną sprawą jest kwestia kosztów, sposobu organizacji i źródeł finansowania placówek opiekuńczych. Pozytywiści postrzegający całość społeczeństwa, jako jeden sprawnie funkcjonujący organizm upatrywali sposobów rozwiązania problemów w wymiarze społecznym przede wszystkim przez rozwój filantropii - dobroczynności warstw oświeconych i zamożnych, uwrażliwionych na ludzką biedę i potrzeby. Ten sposób myślenia prezentuje też Ludwika Ostrowska, podkreślająca dodatkowo konieczność zapewnienia opieki dzieciom z rodzin niezamożnych oraz potrzebę szerokiego kształcenia rzesz ludowych,

\footnotetext{
${ }^{35}$ APŁ, APiOM, Papiery osobiste Ludwiki Ostrowskiej, córki Aleksandra 1851-1926, sygn. II/87.
} 
W szczególności wiejskich kobiet i dziewcząt, dzięki czemu mogłyby one zyskać nowe kwalifikacje i zawodowe możliwości, umniejszające sferę nędzy i bezrobocia na wsi. Idee te Ludwika Ostrowska wcielała w życie w obrębie maluszyńskiego gospodarstwa, sprawując opiekę nad miejscową szkołą i dziećmi, organizując kursy zawodowe dla kobiet i wspierając funkcjonowanie małego szpitalika.

Ten rodzaj postawy łączył w działaniu całą rodzinę Ostrowskich, dzięki czemu ich relacje z maluszyńską gminą i włościanami układały się więcej niż poprawnie. Służyły temu różne formy pomocy i materialnego wsparcia, fundowane stypendia, utworzenie kasy wkładowo-pożyczkowej, czym zajmowała się Helena Ostrowska wspierana przez męża. August Ostrowski w swym testamencie zobowiązał żonę Elizę do utworzenia specjalnego funduszu dla wsparcia włościańskich mieszkańców Radoszewnicy - aby ci ludzie $w$ najbliższym sasiedztwie, $w$ którym spędziłem wraz z Nia najlepsze lata mojego życia, mieli po nas wieczna pamiątkę $e^{36}$.

Do stylu życia ziemian należało tak codzienne, jak i odświętne obcowanie z książką. W ciągu XIX w. księgozbiory dworskie znacznie powiększyły swój biblioteczny stan posiadania. Ich tematyka zależała od zbiorów odziedziczonych po przodkach, od zainteresowań rodziny, poziomu wykształcenia właściciela, pasji kolekcjonerskich itp. Bywały to zbiory niewielkie, liczące kilkaset tomów, większe - kilka tysięcy, istniały też duże księgozbiory zawierające 10-20 tysięcy tomów ${ }^{37}$. Ziemianie gromadzili we dworach słowniki, encyklopedie, beletrystykę polską i francuską, literaturę religijną, książki historyczne, geograficzne, książki o tematyce rolniczej, poezje polskich twórców, literaturę polityczną, prawniczą, rozprawy filozoficzne, pamiętniki, literaturę dla dzieci.

W bibliotece maluszyńskiej znajdowały się liczne odpisy dzieł wydanych w latach 1685-189038. W dokumentach archiwum Ostrowskich zachował się katalog biblioteki maluszyńskiej. Z niego to można wnioskować, że księgozbiór składał się w znacznej mierze z dzieł literatury obcojęzycznej, w tym języka niemieckiego, francuskiego, angielskiego i rosyjskiego. Cała rodzina $\mathrm{z}$ wielkim zapałem zajmowała się tłumaczeniem prac, które stały na półkach biblioteki. Prym wiodła w tej dziedzinie Helena Ostrowska i jej syn August. Zachował się po dzień dzisiejszy niekompletny rękopis tłumaczenia dzieła Gustawa de Boeaumon z o Irlandii ${ }^{39}$. Wyjeżdżając często do Warszawy, gdzie mieszkał mąż Heleny, dziedziczka Maluszyna uczestniczyła w wykładach o literaturze prof. Stanisława Tarnowskiego $^{40}$, czy też zwiedzała wystawy dzieł malarskich, np. Henryka Siemiradzkiego. Odnotowała społeczny rezonans Trylogii Henryka Sienkiewicza, który właśnie zaczął się ukazywać drukiem ${ }^{41}$. Właściciele Maluszyna z wielkim zaangażowaniem podejmowali próby

\footnotetext{
36 APŁ, APiOM, Papiery osobiste Augusta Ostrowskiego, syna Aleksandra 1845-1899, sygn. II/86.

37 J. Kwilecki, Ziemiaństwo wielkopolskie. W kręgu arystokracji, Poznań 2004, s. 111.

38 APL, APiOM, Rękopisy biblioteczne, sygn. IV/15.

${ }^{39}$ APŁ, APiOM, Tłumaczenie dzieła de Beaumon z Irlandii, dokonane przez Helenę Aleksandrową Ostrowską i jej syna Augusta, sygn. II/78.

40 J. Zakrzewski, op. cit., s. 12.

${ }^{41}$ Ibidem.
} 


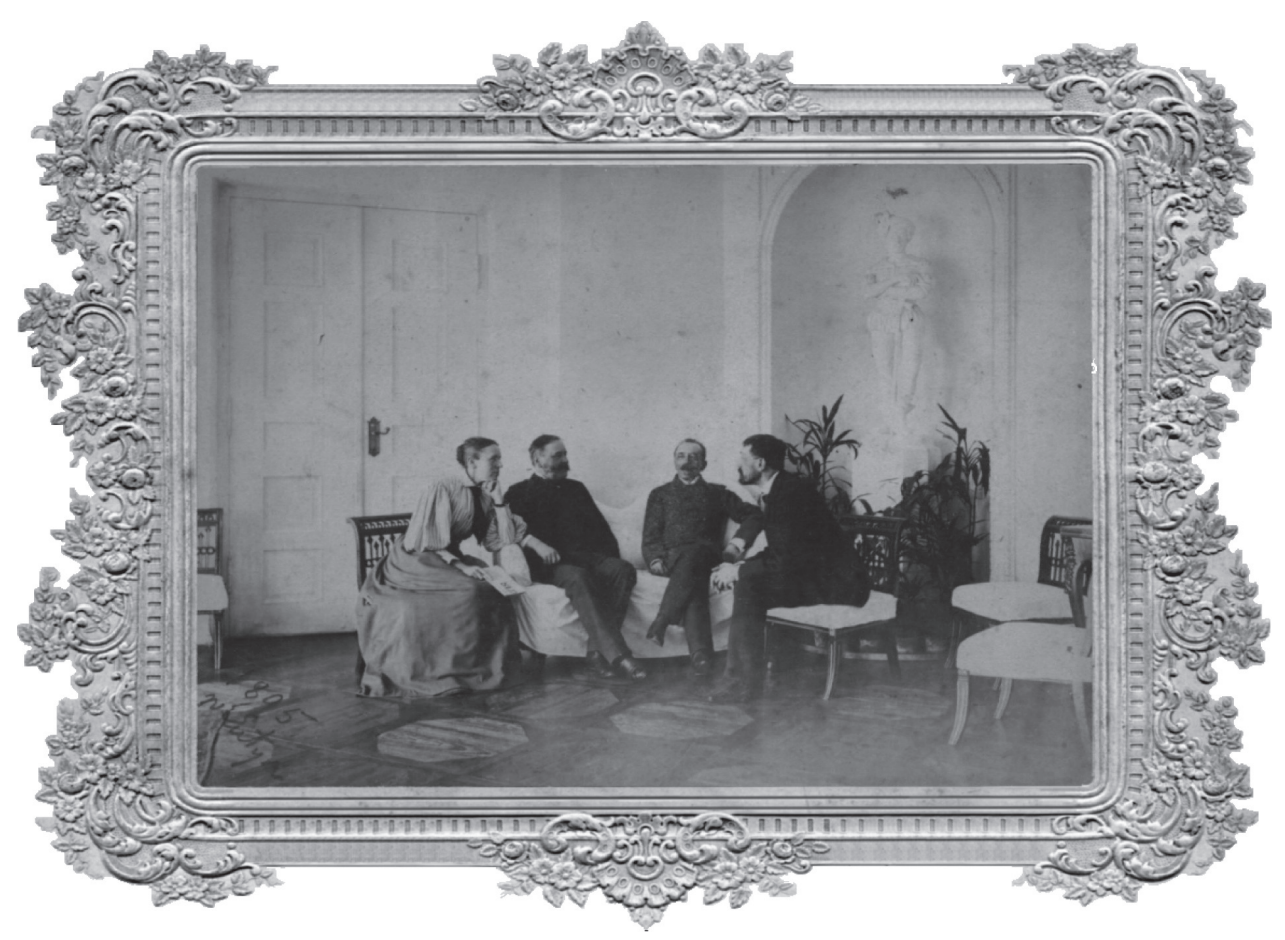

Fot. 8. Ludwika, August, Jan Leon i Józef Ostrowscy we wnętrzu pałacu w Maluszynie Źródto: APŁ, APiOM, Zbiór fotografii i albumów Ostrowskich, Potockich, Morsztynów i rodzin spokrewnionych, sygn. IV/112, f. 265.

własnej twórczości literackiej. W tym kierunku rozmiłowali się głównie Jan Leon i Józef Ostrowscy ${ }^{42}$.

Niezwykle interesującym przykładem erudycji Ostrowskich jest rękopis przygotowywanego dzieła pt. „Opowiadania o historii powszechnej dla ludu wiejskiego"43. Tekst ten, sytuujący się na pograniczu historii i geografii, a nawet religii, tworzony był z myślą o jego druku i - jak sugeruje tytuł - rozpowszechnianiu wśród warstwy włościańskiej (zakładano opublikowanie 3 tomów, obejmujących historię starożytną, średniowieczną i nowożytną oraz mapy). Oto proponowany spis treści tomu pierwszego:

Rozdział I. Jak wyglądała ziemia

Rozdział II. Początki rodu ludzkiego, pierwsze narody w Azji i Afryce

Początki Narodu Żydowskiego

O Egipcie

Historia narodu żydowskiego

42 APŁ, APiOM, Utwory wierszem i prozą Jana Ostrowskiego, sygn. II/81; Ibidem, Utwory dramatyczne Józefa Ostrowskiego, sygn. II/84; Ibidem, Utwory poetyckie Józefa Ostrowskiego, sygn. II/85.

${ }^{43}$ APŁ, APiOM, Papiery Ostrowskich tyczące się popularnej historii powszechnej dla ludu, sygn. II/44. 
Rozdział III. Pierwsze narody w Europie

Grecja

Macedonia

Rzym

Rozdział IV. O innych krajach zamieszkałych w czasie narodzenia Jezusa Chrystusa

Rozdział V. Cesarstwo Rzymskie

Cesarze pogańscy

Cesarze chrześcijańscy

Jak wynika z materiałów archiwalnych, powyższego celu nie udało się zrealizować. Tekst odrzucony został przez Wydawnictwo Dziełek Ludowych oraz Wydawnictwo Towarzystwa Pedagogicznego ${ }^{44}$. To drobne niepowodzenie nie umniejsza jednak znaczenia wysiłków edukacyjnych podejmowanych przez rodzinę Ostrowskich.

W bibliotece maluszyńskiej przechowywano także utwory dedykowane samym Ostrowskim, jak choćby rękopis dla Aleksandra i Heleny z Morstinów Ostrowskich. Autorem był Jan Józef Starożyk ${ }^{45}$. Natomiast Ludwika Ostrowska otrzymywała prace literackie, które dedykował jej Stanisław Grabski ${ }^{46}$.

Przykład dzieci Aleksandra i Heleny potwierdza, że środowisko rodzinne nie tylko zapoczątkowuje działalność wychowawczą, ale także naznacza m.in. dalszą drogę w procesie edukacji, przejmowanym na kolejnych etapach przez szkołę i inne instytucje kształceniowe, wzmacnianym przez wpływy środowiska i przez aktywność własną jednostki, jej talenty i predyspozycje. Przedstawiony obraz właścicieli Maluszyna świadczy też dobitnie o bezpośrednim związku między poziomem wykształcenia ogólnego i wiedzy specjalistycznej. Zdobycie tej wiedzy pozwalało na propagowaniu idei postępu oraz pozytywistycznych haseł pracy organicznej. W domenie Ostrowskich szczególną uwage zwracano na rozwój i kształcenie młodych ludzi pracujących w dobrach maluszyńskich, aby później mogli pracować tu, gdzie pobierali naukę, bądź też przenosić zdobytą wiedzę i zaszczepionego ducha postępu do innych majątków, służąc tym samym rozwojowi kraju. Pod tym względem Ostrowscy - na tle innych rodzin o podobnym statusie społecznym - wyróżniali się w sposób znaczący.

44 Ibidem.

${ }^{45}$ APŁ, APiOM, „, Andrzej Morsztyn, poeta polski XVII w. i jego imiennicy”, sygn. II/79.

46 APŁ, APiOM, Listy Stanisława Grabskiego do Ludwiki Ostrowskiej i prace literackie jej dedykowane, sygn. II $/ 88$. 